\title{
Tilannekuvia suomalaisesta hyvinvointivaltiosta
}

\author{
Juho Saari. Samassa veneessä. Hyvinvointivaltio \\ eriarvoistuneessa yhteiskunnassa. Docendo. Jyväs- \\ kylä 2020. 320 sivua. ISBN 978-952-291-841-3.
}

Sosiaali- ja terveyspolitiikan professori Juho Saari on sekä tutkija että käytännön sosiaalipoliitikko. Tiedeyhteisössä hänet tunnetaan laajasta kirjallisesta tuotannosta. Suuri yleisö tuntee hänet julkisista esiintymisistä ja asiantuntijatehtävistä, kuten toimimisesta Sipilän hallituksen Eriarvoisuutta käsittelevän työryhmän (2018) vetäjänä.

Saaren uusin kirja on jatkoa hänen aikaisemmille hyvinvointivaltiota käsitelleille töilleen (esim. Saari toim. 2005, Saari toim. 2011, Saari 2017), joissa hän on "hahmottanut ajankohtaisia kysymyksiä suomalaisessa elinkeinoelämässä, hyvinvointivaltiossa ja yhteiskunnassa”. Tavallaan Saaren kirjassa yhdistyy tutkijan ja toimijan kaksoisrooli hänen lähestyessään sekä maallikoita että asiantuntijoita. Esipuheessa Saari luonnehtii kirjaansa: "Suurelle yleisölle kohdennetulle Docendo-kirjalle tyypillisesti se on kirjoitettu otsa rypyssä kevyellä kädellä, siis lähtökohtaisesti analyyttisesti, mutta lähteistämättä tekstiä yksityiskohtaisesti”. Ihan helposti tämä ei avaudu, mutta kirjan lukemisen jälkeen tyylilajia ymmärtää paremmin.

Hyvinvointivaltio on usein esillä sekä tutkijoiden töissä että mediassa, lähes aina myönteisenä ja tavoittelemisen arvoisena. Poliitikot, vanhastaan vasemmalta mutta nykyään oikeata laitaa myöten, puhuvat hyvinvointivaltion puolesta. Kansalaisten keskuudessa hyvinvointivaltiolla on vakaa kannatus. Hyvinvointivaltio on kuitenkin monitahoinen ilmiö, ja on selvää, että se voidaan ymmärtää monin eri tavoin. Siksi on paikallaan, että tutkijat tarttuvat aiheeseen ja auttavat meitä saamaan monipuolisen ja selkeän kuvan ilmiöstä nimeltä hyvinvointivaltio.

\section{TILANNEKUVA TAVOITTEENA}

Saari asemoi itsensä seuraavaan tapaan. Ensiksikin, kuten aikaisemmissa töissään, hän käsittelee lähes yksinomaan suomalaista yhteiskuntaa ja hyvinvointivaltiota, etenkin sen sosiaali-, sosiaaliturva- ja terveyspolitiikkaa sekä siinä todettavia sosiaalisia ongelmia. Toiseksi hän kiinnittää itsensä tukevasti valtioneuvoston ja muiden valtionhallinnon elinten asiantuntijatehtäviin. Hän hyödyntää ja ajankohtaistaa työtä, jota hän on tehnyt aikaisemmissa kirjoissaan, valtioneuvoston Eriarvoisuustyöryhmässä (2018) sekä sosiaaliturvan (2019) ja lastensuojelun uudistusten (2019) valmistelussa. Kolmas liittymä on tutkimukseen ja tutkimushallintoon. Saari on toiminut Suomen Akatemian strategisen tutkimuksen neuvostossa (2014-2018) sekä akateemisissa johtotehtävissä, vuodesta 2019 dekaanina Tampereen yliopistossa. Kirjoittajan aktiivisuus on kunnioitettava, suorastaan hengästyttävä.

Saaren kunnianhimoisena tehtävänä on piirtää "tilannekuva" suomalaisesta hyvinvointivaltiosta ja yhteiskunnasta siten, että sen "ytimessä ovat sosiaali- ja terveyspolitiikan ja hyvinvointija terveyserojen väliset leikkauspinnat". Teoreettisesti hän sanoo nojautuvansa taloussosiologiaan ja institutionaaliseen taloustieteeseen. Taloussosiologisessa tarkastelussa ihmisten toimintaa ohjaavat rationaaliset valinnat. Institutionaalisessa tarkastelussa taas kansalaiset ovat yhteiskunnan instituutioiden kohteita ja samalla sosiaalisten oikeuksien omistajia. Sosiaalitieteitä hän ei erikseen mainitse.

Tilannekuvan tai tilannekuvien tavoittelu tekee kirjasta ajankohtaisen, se painottuu lähihistoriaan, nykyhetkeen ja tulevaisuuden näköaloihin. Se jakautuu kahteen pääosaan. Jaksoissa 1-3 kohteena on hyvinvointivaltio yleisemmin sekä eriarvoisuus suomalaisessa yhteiskunnassa. Jaksoissa 4-8 katse suunnataan tulevaisuuteen, joskin sitä peilataan edelleen nykytilaan. Silmä- 
määränä ovat suomalaisen hyvinvointivaltion tulevaisuus ja muutostarpeet.

Näistä lähtökohdista Saari analysoi yhtäältä sosiaali- ja terveyspolitiikan institutionaalista muutosta estäviä ja edistäviä tekijöitä. Toisaalta kohteena ovat hyvinvointivaltion institutionaaliseen rakenteeseen iskostuneet eriarvoistavat mekanismit, jotka muodostuvat intressiryhmien toiminnan ja yhteiskunnan rakenteellisten ja kulttuuristen jakojen tuloksena. Poliittisesti kysymys on siitä, ketkä hyötyvät ja ketkä joutuvat maksumiehiksi niissä rajoissa, jotka "väestörakenteen, työllisyyden ja julkisen talouden kolmiyhteys" kulloinkin asettaa. Hyvinvointivaltion kiinteä institutionaalinen rakenne lähestyy funktionaalista yhteiskuntanäkemystä.

\section{HYVINVOINTIVALTION KRITEERIT}

Hyvinvointivaltion toteutumista Saari tarkastelee kymmenen kriteerin avulla. Lista lienee hänen itsensä kokoama, lähdeviitteitä ei esitetä. Hyvinvointivaltion tunnusmerkkeihin kuuluvat muun muassa väestöryhmien sosiaaliset oikeudet kattava perustuslaki ja lainsäädäntö, sosiaalisten riskien ja sosiaalisten ongelmien määrittelyyn ja hallintaan perustuva sosiaali- ja terveyspoliittinen järjestelmä, julkisten varojen kohdentaminen sosiaaliturvaan, työllisyyteen, koulutukseen, terveyteen ja hyvinvointiin sekä elintason ja elämänlaadun turvaamiseen ja edistämiseen siten, että erityistä huomiota saavat huono-osaiset ryhmät. Viimeisenä kriteerinä listataan vielä tilastointi, tutkimus ja tietoperustainen päätöksenteko.

Kun kriteerit täyttyvät, on perusteltua puhua nykyaikaisesta hyvinvointivaltiosta. Selvää systematiikkaa listatuista kriteereistä tuskin kannattaa hakea, jollei sellaisena pidetä hyvinvointivaltion institutionaalista luonnetta, sen poliittista, hallinnollista ja juridista ylärakennetta. Väestöryhmien erilaiset intressit sekä sosiaalisista riskeistä kärsivät huono-osaiset ryhmät, kuten työkyvyttömät ja sairaat mainitaan, mutta yhteiskunnan rakenteellinen tarkastelu ja ristiriidat sekä väestöryhmittäiset jaot ovat toissijaisessa asemassa.

Saari viittaa Mitä-Missä-Milloin -kirjaan, johon puhe uudesta yhteiskuntamallista, hyvinvointivaltiosta ilmaantui vuonna 1954. Hyvinvointivaltion idea ja sen toteutus ovat kuitenkin kehkeytyneet runsaan sadan vuoden aikana. Tätä prosessia hän kuvaa riskien hallinnan institutionaalisena historiana, ennen muuta harjoitetun sosiaali- ja terveyspolitiikan ja toteutuneiden reformien historiana. Suomi saavutti hyvinvointivaltion kymmenen kriteeriä pääpiirtein jo 1980luvulla. Nykyään yhteiskuntamalli on osa suomalaisten identiteettiä, mielipidetutkimuksissa jopa 85 prosenttia suomalaisista pitää hyvinvointivaltiota tärkeänä. Kirjoittajalle tämä kansallinen projekti on menestystarina, hyvinvointivaltion eroosiosta tai kriisistä hän ei puhu.

Rajoittuessaan Suomeen Saari ei tarkastele eri hyvinvointivaltioiden samanlaisuutta tai erilaisuutta. Hän tyytyy viittaamaan Esping-Andersenin (1990) tunnettuun hyvinvointiregiimien typologiaan: konservatiivinen, liberaali ja sosiaalidemokraattinen regiimi. Pohjoismaat muodostavat sosiaalidemokraattisen regiimin, jossa Ruotsin malli on usein toiminut kehittyneen hyvinvointivaltion paradigmana ja vertailukohtana suppeammille ja vähemmän kehittyneille malleile. Saarella on vankka EU:n tuntemus, joten laajempi eurooppalainen tarkastelu tarjoaisi kiinnostavan lisän.

\section{ERIARVOISUUS}

Pohjoismaisen hyvinvointivaltiomallin tunnusmerkkeihin kuuluvat universaalit etuudet, etuuksien suhteellisen korkea taso sekä pyrkimys yhteiskuntaluokkien ja sukupuolten välisen eriarvoisuuden vähentämiseen (Kautto ym. 2001). Saari käy keskustelua huono-osaisista ryhmistä ja huono-osaisuuden ylisukupolvisuudesta eli "periytymisestä”. Yhteiskunnalliseen marginaaliasemaan joutuminen merkitsee vakavaa huono-osaisuutta. Eriarvoisuus ei silti rajoitu vain "alamarginaaliin”, vaan läpäisee koko sosiaalisen rakenteen alimmista asemista keskiryhmiin ja ylempiin asemiin.

Kirjoittaja toteaa, että ”asuminen, tulot ja terveys ovat kytköksissä sosioekonomiseen asemaan", ja jatkaa sitten, että "nämä asiat ovat kyllin monta kertaa ja kiistatta osoitettu, joten ne eivät vaadi tässä yhteydessä sen suurempaa keskustelua”. Aivan itsestään selvistä asioita ei kuitenkaan ole kysymys, ja tilannekuva jää vajaaksi ilman väestöryhmien välisen eriarvoisuuden ja sen eri ilmenemismuotojen tarkastelua. Sosioekonominen asema, koulutus, ammattiasema ja tulot yhdessä sukupuolen, iän ja etnisen taustan 
kanssa, muodostaa yhteiskunnan hierarkkisen perusrakenteen ja eriarvoisuuden kasvualustan.

Tärkeä erottelu koskee eriarvoisuuden suhteellista ja absoluuttista luonnetta. Terveyserojen tutkimuksessa on usein selvitetty suhteellista eriarvoisuutta, kuten kuolleisuus ylimmässä sosiaalisessa asemassa suhteessa alimpaan. Absoluuttinen eriarvoisuus, kuten kuolleiden lukumäärä ylemmissä ja alemmissa asemissa, on terveys- ja hyvinvointipolitiikan kannalta kuitenkin yhä tärkeämpi kohde. Saari vaikuttaa olevan kallellaan suhteellisen eriarvoisuuden suuntaan todetessaan, että "ihminen on vertaileva olento", jolloin "alhainen suhteellinen asema taas aiheuttaa ihon alle menevää arviointiahdistusta, joka puolestaan lisää erilaisia sosiaalisterveydellisiä ongelmia”. Kysymyksellä siitä, tarkastellaanko suhteellisia vai absoluuttisia eroja, on sekä teoreettisesti että yhteiskuntapoliittisesti suuri merkitys. Suhteellisen eriarvoisuuden selitykset ovat usein psykologisia, kuten ahdistus tai stressi. Absoluuttisen eriarvoisuuden selityksiä taas ovat yhteiskunnan aineelliset, taloudelliset ja sosiaaliset resurssit. Suhteellisten erojen kaventaminen tähtää yhteiskunnassa vallitsevan eriarvoisuuden vähentämiseen sinänsä, absoluuttisten erojen kaventaminen taas tähtää yksilöiden ja ryhmien elinolojen parantamiseen ja resurssien tasa-arvoisempaan jakautumiseen.

\section{TULEVAISUUS}

Hyvinvointivaltion tulevaisuuden pohdinnassa nousee institutionaalinen näkökulma jälleen esille. Yhteiskunnan makrokehitystä tarkasteltaessa kohteena on valtiontalous, erityisesti sosiaali- ja terveydenhuollon menotalous. Tulevaisuuden solmukohtia Saari taustoittaa jo toteutuneella kehityksellä. Hän palaa toistuvasti "kolmiyhteyteen", jossa väestörakenne, ikääntyminen ja maahanmuutto, määrittävät työllisyyttä ja nämä yhdessä julkista taloutta. Taustalla väijyy kestävyysvajeen uhka: miten julkinen talous selviää, kun ikääntyvien ryhmien suhteellinen osuus väestössä kasvaa ja vakavan hoivan tarve lisääntyy ilman että työllisyysaste nousee. Alhainen syntyvyys ja korkea työttömyys rasittavat edelleen kestävyysvajetta.

Sosiaalimenot ovat kasvaneet jatkuvasti jo vuosikymmenten ajan, kuten kirjan graafista ilmenee. Miten jatkossa selvitään? Yksi sopeutumismalli on eläkeläisten laajamittaisempi osal- listuminen ansiotyöhön. Toinen sopeutumismalli on maahanmuuton lisääminen, joka samalla voi kompensoida vanhimpien ikäryhmien kasvavaa osuutta ikärakenteessa. Sosiaalimenojen rahoituslaskelmissa huomiota kiinnittää viime vuosikymmenien kehitys: työnantajien osuus on laskenut jyrkästi, kun taas kuntien ja vakuutettujen eli kansanlaisten osuus on kasvanut.

Tulevaisuuteen varautumista Saari tarkastelee pääasiassa hallinnollisella ja valtion talouden tasolla. Samalla hän sivuaa myös isoja periaatteellisia kysymyksiä, kuten yhteiskunnan vaurautta: pitääkö aina vain vaurastua ja jos pitää, niin millä vauhdilla. Keskittymisestä Suomeen seuraa, ettei globaaleja kysymyksiä käsitellä laajemmin. Ilmastonmuutos ja YK:n kestävän kehityksen toimintaohjelma Agenda 2030 nostetaan kuitenkin esille ja pohditaan, miten maailmanlaajuiset haasteet muovaavat tulevaisuuden yhteiskuntapolitiikkaa ja miten Suomi näihin uusiin haasteisiin vastaa. Saari huomauttaa aiheellisesti, että Agenda 2030 sisältää useita sosiaali- ja terveyspoliittisia kysymyksiä, ja eriarvoisuuden vähentäminen maiden sisällä ja välillä on yksi ohjelman tavoitteista. Tasa-arvon toteutuminen muun muassa yhteiskuntaluokkien, sukupuolten, ikäryhmien sekä maahanmuuttajien ja etnisten ryhmien välillä on tärkeä testi hyvinvointivaltion onnistumiselle 2000-luvulla.

\section{TERVEYS}

Kirjan ytimessä on sosiaalipolitiikka, mutta siellä täällä esillä ovat myös terveyspolitiikka, terveydenhuolto ja väestön terveys. Sote-uudistukseen Saari ei tohdi kajota. Nopeana tarkkailijana hän on kuitenkin ehtinyt ottaa koronapandemian huomioon. Pandemiaan viitataan toistuvasti ja sitä käsitellään myös omassa jaksossaan vuoden 2020 puoleen väliin saakka. Toinen aalto nousi vasta, kun kirja oli jo painossa.

Pandemia saa oikeutetusti suuren yhteiskunnallisen merkityksen: "Covid-19-pandemia on hyvinvointivaltion stressitesti, jonka vaikutukset voidaan luotettavasti arvioida vasta 2020-luvun lopulla”. On hyvä, ettei sitä käsitellä irrallaan, vaan osana koko yhteiskuntaa ja sen terveys- ja yhteiskuntapolitiikkaa. Tärkeitä kysymyksiä ovat, millaisia vaurioita covid-19 aiheuttaa kansanterveydelle, kansantaloudelle, perheille ja yksilöille, ja kuinka eriarvoisesti vauriot jakautuvat. Suomi 
on toistaiseksi selvinnyt hyvin useimpiin muihin maihin verrattuna. Pohjoismaisista hyvinvointivaltioista Ruotsin pandemiakehitys on ollut muita huonompi. Lopulta voidaan kysyä, muuttaako pandemia koko hyvinvointivaltiota.

Vaikka sosioekonomisten ryhmien väliset terveyserot jäävät mainintojen varaan, niiden tarkastelu olisi sopinut hyvin kirjaan. Aihepiirin johtaviin tutkijoihin kuuluvan Johan Mackenbachin (2019) mukaan sosioekonomisten terveyserojen säilyminen kehittyneimmissäkin pohjoismaisissa hyvinvointivaltioissa on "suuri pettymy" ja "samalla valtava paradoksi", jota "vaikea hyväksyä, mutta myös vaikea ymmärtää". Terveyserot kertovat rakenteellisesta eriarvoisuudesta ja hyvinvointivaltion (epä)onnistumisesta. Suomessa on tehty runsaasti aihepiirin tutkimusta, ja myös THL:n asiantuntijat ja viranomaiset ovat kiinnittäneet terveyseroihin huomiota ja laatineet ohjelmia terveyserojen kaventamiseksi.

\section{LOPUKSI}

Aika ajoin on haikailtu hyvinvointivaltion "kultaajan”, 1980-luvun perään. Saaren mukaan tällaiselle kulta-ajalle ei ole perusteita, eikä nykyinen hyvinvointivaltio ole kriisiytynyt tai murenemassa. Suomi täyttää hyvinvointivaltion kriteerit, eikä uudistustarpeista mikään ei kyseenalaista hyvinvointivaltion säilymistä myöskään tulevaisuudessa. Saari vetoaa Suomen menestykseen erilaisissa kansainvälisissä listauksissa, mutta ei välty hybrikseltä todetessaan, että Suomi on "kaiken kaikkiaan yksi maailman parhaista maista" ja "jo nyt maailman esikuvia”.

Saaren analyysit perustuvat yleensä hallinnollisiin tilastoihin ja selvityksiin, siellä täällä myös mielipidetutkimuksiin. Näistä lähteistä syntyy "tietovaranto", jota valtioneuvosto, ministeriöt ja muu hallinto soveltavat sosiaali- ja terveyspolitiikan ja muun yhteiskuntapolitiikan toimeenpanossa. Suomalaista ja varsinkaan kansainvälistä perustutkimusta ei ainakaan eksplisiittisesti hyödynnetä.

Hallinnollisen ja poliittisen tason tilannekuva olisi hyötynyt perustutkimuksen tuesta. Väestötason ja väestöryhmien tarkastelu taas olisi täy- dentänyt eriarvoisuuden tilannekuvaa. Tutkimuksen ja lähdeviitteiden rohkeampi käyttö sekä painopisteen laajentaminen väestötasolle ei olisi kirjan perusluonnetta muuttanut. Lisäykset olisivat kuitenkin laajentaneet mahdollisuuksia tarkastella hallinnollisten ja poliittisten päätösten heijastumista väestön hyvinvointiin ja sen tasa-arvoiseen jakautumiseen nyt ja tulevaisuudessa.

Saaren tavoitteena on ollut tuottaa tilannekuva suomalaisesta hyvinvointivaltiosta ja tilannekuvia yhteiskunnan eri osa-alueilta laajalle lukijakunnalle. Kirjan sävy on optimistinen ja siinä etsitään ratkaisuja tulevaisuuden haasteille. Se on ajankohtainen, monipuolinen ja aineksiltaan rikas. Yhteiskunnan institutionaalisen ylärakenteen, valtionhallinnon ja -talouden sekä sosiaali- ja sosiaaliturvapolitiikan tarkastelu on kirjan vahvinta antia.

\section{LÄHTEET}

Eriarvoisuutta käsittelevän työryhmän loppuraportti. Valtioneuvoston kanslian julkaisusarja 1/2018, Helsinki 2018.

Esping-Andersen G. Three worlds of welfare capitalism. Princeton University Press, Princeton 1990. https://doi.org/10.1177/095892879100100108

Kautto M, Fritzell J, Hvinden B, Kvist J, Uusitalo H. Introduction. How distinct are the Nordic welfare states? Kirjassa: Kautto M ym. (toim.). Nordic welfare states in the European context. Routledge, London 2001, s. 1-17.

Mackenbach J. Health inequalities. Persistence and change in European welfare states. Oxford University Press, Oxford 2019. https://doi.org/10.1093/ oso/9780198831419.001.0001

Saari J (toim.). Hyvinvointivaltio. Suomen mallia analysoimassa. Yliopistopaino, Helsinki 2005.

Saari J (toim.). Hyvinvointi. Suomalaisen yhteiskunnan perusta. Gaudeamus, Helsinki 2011.

Saari J. Hyvinvointivaltio markkinayhteiskunnassa. Yhteiskuntapolitiikka 2017:82:479-485.

\section{Eero Lahelma}

Professori

Helsingin yliopisto

Kansanterveystieteen osasto 